\title{
SINERGI OPOSISI BINER: FORMULASI TUJUAN DASAR LAPORAN KEUANGAN AKUNTANSI SYARI'AH
}

\author{
Iwan Triyuwono \\ Fakultas EkonomiUniversitas Brawijaya Malang
}

\begin{abstract}
Abstrak
Wacana akuntansi syari'ah di Indonesia perlu dikembangkan tidak saja pada level filosofis, tetapi ke arah teori yang lebih konkrit. Makalah ini pada dasarnya bertujuan untuk memberikan kontribusi bagi akuntansi syari'ah pada level teori, yaitu, khususnya memformulasilkan tujuan dasar (basic objectives) dari laporan keuangan (financial statements) akuntansi syari'ah.

Alat analisis yang digunakan dalam makalah ini adalah sinergi oposisi biner yang diilhami oleh nilai-nilai dari tradisi Islam dan Tao. Alat analisis ini pada dasarnya menggabungkan dua hal yang berbeda (dan bahkan bertolak belakang) menjadi satu kesatuan yang tidak terpisahkan, misalnya hibrida antara nilai-nilai maskulin dengan feminin, egoistik dan altruistik, materi dan spiritual, dan lain-lainnya.

Dari hasil analisis dapat diformulasikan bahwa tujuan dasar laporan keuangan akuntansi syari'ah adalah untuk memberikan: (1) akuntabilitas dan (2) informasi. Akuntabilitas merupakan representasi dari unsur spirit (ruh, atau, jiwa), atau unsur etika, atau unsur ukhrawi, atau unsur feminin. Sedangkan informasi merupakan representasi dari unsur materi, atau unsur ekonomi, atau unsur duniawi, atau unsur maskulin. Kedua tujuan dasar tersebut menjadi satu-kesatuan yang tidak terpisahkan dan menjadi kekuatan dari akuntansi syari'ah.
\end{abstract}

Key words: sinergi oposisi biner, maskulin, feminin, akuntabilitas, dan informasi.

\section{PENGANTAR}

Beberapa waktu terakhir ini, wacana akuntansi syari'ah terasa semakin menampakkan getarannya, mulai dari kajian filosofis hingga pada kajian teoritis (lihat misalnya Harahap 1997; Triyuwono 1997; 2000a; 2000b; Triyuwono dan As'udi 2001; lihat juga Gambling and Karim 1991; Baydoun and Willett 1994). Wacana ini memberikan kontribusi yang sangat berarti bagi perkembangan akuntansi khususnya di Indonesia. Paling tidak kajian ini "meleburkan" dinding pembatas antara disiplin akuntansi dan nilai-nilai agama.

Triyuwono dan As'udi (2001), misalnya, mencoba untuk "turun" mewacanakan akuntansi syari'ah pada tingkat yang lebih konkrit pada tataran teori (lihat juga Harahap 1997), yaitu mengkonsep laba dalam konteks metafora zakat. Wacana yang dikembangkan pada dasarnya menekankan pada metode penilaian income. Kajian ini tentunya berasumsi bahwa akuntansi syari'ah mengembangkan "bentuk" dirinya berdasarkan pada nilai-nilai zakat (Triyuwono 1997; 2000a; 2000b). Asumsi ini juga tidak bisa terlepas dari "teori akuntansi" (accounting point of view) (lihat Kam 1990) yang dianut.

Setiabudi (2000), misalnya, secara implisit "menganut" entity theory untuk melihat dan menjustifikasi konsep akuntansi ekuitas dari sudut pandang Islam. Sebaliknya, Slamet (2001) justru menggunakan enterprise theory (yang kemudian dimodifikasi dengan menginternalisasikan nilai Islam) untuk mengembangkan teori akuntansi syari'ah. Kedua teori tersebut memiliki dasar filosofis yang berbeda, sehingga 
keduanya memiliki karakter yang berbeda. Dengan karakter tersebut, masing-masing teori memiliki tujuan yang berbeda pula.

Makalah ini mencoba untuk membahas tujuan dasar (basic objectives) dari akuntansi syari'ah dengan merujuk dan membandingkan konsep yang ada pada entity theory dan enterprise theory. Struktur penulisan makalah ini dimulai dengan analisa kritis terhadap entity theory yang kemudian dilanjutkan pada enterprise theory. Kemudian, makalah ini mendeskripsikan "epistemologi oposisi biner" yang dijadikan dasar justifikasi untuk memformulasikan tujuan dasar laporan keuangan akuntansi syari'ah.

\section{ENTITY THEORY: UNIFIKASI KEKUASAAN EKONOMI}

Ide utama dari entity theory ini adalah memahami perusahaan sebagai entitas yang terpisah dari pemiliknya. Teori ini muncul dengan maksud mengurangi kelemahan-kelemahan yang ada dalam proprietary theory di mana proprietor (pemilik) menjadi pusat perhatian (Kam 1990, 302306). Namun demikian, entity theory pada dasarnya tidak berbeda jauh dengan teori pendahulunya, proprietary theory.

Dalam konteks teori ini, terdapat dua pandangan yang berbeda walaupun keduanya mengarah kepada konklusi yang sama, yaitu stewardship atau pertanggungjawaban (accountability) (Kam 1990, 306). Versi pertama adalah versi tradisional yang memandang bahwa perusahaan beroperasi untuk keuntungan pemegang saham, yaitu orang-orang yang menanamkan dananya dalam perusahaan. Entitas bisnis, dengan demikian, memperlakukan akuntansi sebagai laporan kepada pemegang saham tentang status dan konsekuensi dari investasi mereka. Sementara itu versi kedua - yaitu pandangan yang lebih baru terhadap entity theory - menganggap bahwa sebuah entitas adalah bisnis untuk dirinya sendiri yang berkepentingan terhadap kelangsungan hidup dan perkembangannya. Menurut Paton yang dikutip Kam dikatakan bahwa:

It is "the business" whose financial history the bookkeeper and accountant are trying to record and analyzed; the books and accounts are the record of "the business"; the periodic statements of operations and financial condition are the reports of "the business" (1990, 306).

Karena dikonsentrasikan untuk resistensi dan ekspansi, entitas bisnis memberikan laporan akuntansi kepada pemegang saham hanya dalam rangka memenuhi persyaratan legal dan untuk mengelola hubungan baik dengan mereka dalam konteks bahwa sejumlah dana tambahan mungkin dibutuhkan di masa depan.

Meskipun kedua versi tersebut menempatkan entitas sebagai unit independen, namun terdapat sedikit perbedaan konsep di antara keduanya. Pandangan tradisional masih memposisikan pemegang saham sebagai "partisipan" (associates), sementara sudut pandang baru lebih memposisikan mereka sebagai pihak luar (outsiders). Tetapi ini tidak mempengaruhi muatan informasi dari laporan akuntansi yang disajikan oleh entitas tersebut.

Meskipun konsep entity theory merupakan pengembangan dari konsep proprietary theory, namun bila diinterpretasikan secara kritis (khususnya dalam konteks konsep kepemilikan), sebagian besar muatannya tetap berbasiskan aspek-aspek ideologis yang sama dengan konsep proprietary theory.

Beberapa aspek ideologis ini dapat diterangkan dengan cara, seperti: pertama, walaupun konsep entity tidak mengekspresikan diri sebagai konsep kepemilikan mutlak, tetapi konsep ini tetap melanjutkan proyek sebelumnya yang mengemban semangat perolehan dan akumulasi kekayaan tanpa batas. Absoluditas kepemilikan individu yang disimbolisasikan oleh konsep proprie- 
tary tidak digunakan lagi, hak dan kewajiban pemilik menjadi terbatas terhadap kekayaan perusahaan. Sebagai gantinya, entitas bisnislah yang sekarang memiliki kekuasaan untuk memanfaatkan pendapatan dan kekayaannya sendiri, tentu saja dengan orientasi tetap untuk kesejahteraan pemilik perusahaan. Artinya sama saja. Entitas bisnis akhirnya berperan sebagai agen pemilik perusahaan dengan orientasi perolehan dan kekayaan secara tak terbatas, baik untuk kesejahteraan pemilik maupun untuk survivalitas dan perkembangannya sendiri. Bahkan lebih mengerikan lagi, kehendak akumulasi kekayaan ini sekarang harus diatributkan kepada entitas bisnis yang berlaku sebagai mesin perang tanpa pertimbangan etis, karena ia hanya alat, bukan orang atau sekelompok orang yang harus bertanggung jawab atas perilakunya.

Kedua, kemutlakan hak kepemilikan tidak terletak pada kekuasaannya untuk merealisasikan kekayaan, tetapi pada terbebasnya kekuasaan tersebut dari pertanyaan yang bersifat etis kemanusiaan. Transformasi pusat perhatian dan orientasi kekayaan dari pemilik kepada perusahaan sebagai entitas bisnis yang terpisah dari pemiliknya merupakan kreatifitas luar biasa dari konsep ini untuk menyelubungi problem normatifetis perilaku Kapitalisme yang dipraktekkan dunia bisnis. Karena pemilik kekayaan adalah entitas bisnis itu sendiri, pemilik perusahaan tidak perlu lagi terbebani dengan pertanyaan etis tentang harta kekayaannya. Konsep entity pun tidak perlu memperhitungkan legitimasi semacam itu karena ia dianggap alat yang netral dan memiliki personalitas tersendiri yang independen dari kepentingan perorangan. Sementara itu, problem legitimasi normatif-etis kekayaan pemilik dianggap bukan merupakan concern konsep ini karena pemilik dianggap sebagai pihak eksternal (outsiders).

Ketiga, sudut pandang konsep entity dengan demikian memberikan basis "rasio- nalitas" baru terhadap orientasi kekayaan tak terbatas, yaitu legitimasi "normatif-etis" dengan bentuk persamaannya itu. Selain perhitungan rasional, konsep entity menawarkan basis rasionalitas baru sebagai legitimasi, yaitu perilaku kapitalistis entitas bisnis yang memperoleh legitimasi atas perilakunya itu hingga menjadi sah secara etis. Ini terjadi justru karena ketiadaan dasar normatif-etis itu sendiri sehingga secara logis dapat dikatakan ia memperoleh legitimasi normatif-etis dengan cara itu, karena ia tidak perlu memenuhi unsur-unsur etis apapun. Dengan sifatnya yang "non-etis", ia tidak perlu legitimasi normatif-etis. Maka wajarlah bila konsep ini kemudian menimbulkan paradoks yang tampak "rasional" dalam makna "ekuitas", di mana dengan definisi dan pencantumannya sebagai "hak kepemilikan" dalam akuntansi ia seharusnya didasarkan pada teori etis tertentu. Tetapi di sisi lain, karena konsep ini memisahkan pemilik dengan entitas bisnisnya, hak kepemilikan pemilik dianggap berada di luar wilayahnya dan diposisikan sebagai nilai residu yang tidak perlu dilegitimasi secara tersendiri.

Baik implisit atau eksplisit, dalam entity theory terlihat adanya principal-agent relationship, yaitu hubungan antara pemilik (shareholders) dan agen (management) yang dalam mainstream accounting dianggap konsep yang obyektif dan netral (bebas nilai) (Chwastiak 1999). Dalam kenyataannya, konsep ini sebetulnya tidak netral, sebagaimana dikatakan oleh Chwastiak berikut ini:

...the theory [principal-agent relationship] actually imposes a capitalistic subjectivity on the object of the research, labor, and in so doing, rationalizes and legitimizes exploitation... the principal-agent model's ideological strength and resilience lies in its ability to rationalize, normalize, and legitimize various means of controlling the labor process in such a way that it appears as 
if labor benefits from its own degradation and exploitation (1999, 425).

Dari komentar di atas dapat dilihat bahwa konsep tersebut sama sekali tidak obyektif dan netral, tapi sebaliknya ia sarat dengan nilai kapitalistik yang dalam faktanya sangat eksploitatif. Principal-agent relationship secara samar memiliki kemampuan untuk merasionalkan, menormalisasi, dan melegitimasi berbagai macam instrumen yang digunakan untuk mengendalikan buruh yang seolah-olah kaum buruh memperoleh banyak manfaat dari sistem yang sesungguhnya sangat eksploitatif.

Lebih lanjut Chwastiak (1999, 429) menjelaskan bahwa dengan model tersebut semua tindakan manusia dilakukan dengan cara yang "rasional." Padahal, dalam kenyataannya, rasionalitas meniadakan instrumen "rasa" dan "intuisi" yang ada dalam diri manusia, serta meniadakan mutual assistance dan reciprocal recpect yang hidup dalam masyarakat. Rasionalitas, dengan demikian, mengidentitaskan dirinya pada logika kuantitatif dan kalkulatif yang terpisah dari unsur-unsur "irrasional" (atau superrasional). Sikap ini tidak memberikan tempat pada trust dan fairness yang sebetulnya juga merupakan perilaku manusia yang hakiki (Chwastiak 1999, 429; Baiman 1990, 345). Rasionalitas principal-agent relationship tidak lebih dari rasionalitas utilitarianisme di mana semua kalkulasi berpulang pada utilitas-hedonis yang implikasinya memang dapat memarginalkan sifat-sifat "feminin" manusia (seperti: rasa, intuisi, spiritual, saling membantu, saling menghormati, saling percaya, jujur, dan lainlainnya).

Pengaruh rasionalitas ini juga terlihat pada formulasi dari tujuan laporan keuangan yang didefinisikan oleh, accounting body di Amerika Serikat seperti yang terlihat di bawah ini:

The basic objective of financial statements is to provide information useful for making economic decision (Mathews and Perera 1993, 76).

Tujuan dasar laporan keuangan seperti yang diungkapkan di atas secara implisit merefleksikan kepentingan investor (atau stockholders sebagai principal) atas manfaat ekonomi dari apa yang telah diinvestasikan. Untuk itu, pihak investor membutuhkan informasi akuntansi untuk pengambilan keputusan (misalnya untuk tetap melakukan investasi atau tidak).

Lebih jauh juga diungkapkan bahwa laporan keuangan tidak saja memperhatikan kepentingan investos, tetapi juga kreditor, seperti terlihat di bawah ini:

An objective of financial statements is to provide information useful to investors and creditors for predicting, comparing, and evaluating potential cash flows to them in terms of amount, timing, and related uncertainty (Mathews and Perera 1993, 76).

Secara khusus dapat dikatakan bahwa informasi akuntansi disajikan pada dua pihak, yaitu investor dan kreditor, di mana keduanya merupakan pihak yang memasok "modal" (sebagai "pemilik modal") pada perusahaan dan mereka mengharapkan adanya return yang menguntungkan atas apa yang telah mereka investasikan. Sebagai pemasok modal (atau sebagai principal), investor dan kreditor menghendaki adanya informasi tentang seberapa jauh manajemen (agent) telah mengelola sumber daya tadi dengan baik. Oleh karena itu tidak aneh bila tujuan yang lain dari laporan keuangan dinyatakan sebagai berikut:

The objective of financial statements is to supply information useful in judging management's ability to utilize enterprise resources effectively in achieving the primary enterprise goals (Mathews and Perera 1993, 76).

Jadi, laporan keuangan merupakan instrumen yang digunakan untuk memberikan informasi tentang kinerja dari mana- 
jemen. Dengan informasi tersebut penilaian kinerja manajemen dilakukan oleh principal; dan principal sekaligus dapat mengambil keputusan.

Dari tiga macam tujuan laporan keuangan yang telah diungkapkan di atas, dapat diketahui bahwa formula tujuan laporan keuangan sesungguhnya tidaklah benarbenar netral. Formula tersebut memiliki bias nilai, yaitu mementingkan kepentingan pemilik modal, yang pada dasarnya tetap menghegemoni pihak "lain" (the others).

Yang menjadi kepentingan pemilik modal di sini adalah mempertahankan modal yang ditanam (capital maintenance) sekaligus mendapatkan laba yang maksimal. Dalam konteks ini Chwastiak (1999, 437) mengatakan bahwa:

Accounting, as currently practiced, helps to maintain a culture of exploitation by depicting benefit as being created through negation and by subordinating human and natural diversity to the monolithic objective of profit maximization. Such a measure of value denies the inherent worth in objects by submitting them to a capitalistic subjectivity and, as previously mentioned, this in turn increases the efficacy of exploitation.

Hal yang krusial di sini adalah bahwa akuntansi menjadi kendaraan yang dikuasai oleh pemilik modal (dalam sistem ekonomi kapitalis) di mana kekuasan tunggal ekonomi berada pada tangan kapitalis. Akuntansi akhirnya cenderung memperkuat budaya ekploitasi. Dan eksploitasi ini tidak saja dilakukan terhadap pihak-pihak lain dari stakeholders, tetapi juga eksploitasi terhadap alam.

\section{ENTERPRISE THEORY: DIVERSIFIKASI KEKUASAAN EKONOMI}

Proprietary theory dan entity theory (serta principal-agent relationship) merupakan wujud dari model instrumen bisnis pada masa lalu yang masih sederhana (dan sistem kapitalisme). Pada kondisi bisnis yang sederhana tersebut, posisi proprietary atau owner (principal) sangat sentral dan penting. Pemilik perusahaan adalah satusatunya person yang memiliki kekuasaan atas perusahaan dan bisnis yang dilakukannya dan di tangannya pula keberlangsungan hidup perusahaan bergantung.

Namun sebaliknya, model bisnis kontemporer sekarang ini sangat berbeda dengan model bisnis masa lalu. Artinya, keberlangsungan hidup perusahaan tidak ditentukan oleh pemilik perusahaan, tetapi oleh banyak pihak (seperti, pelanggan, kreditor, manajemen, pegawai, pemasok, pemerintah, dan lain-lainnya yang kemudian disebut stakeholders) yang juga sama-sama memiliki kepentingan terhadap perusahaan. Dengan kata lain, berhasil-tidaknya sebuah perusahaan sebetulnya bergantung pada keharmonisan interaksi antara pihak-pihak yang berkepentingan, yaitu stakeholders. Konsep ini menunjukkan bahwa kekuasaan ekonomi tidak lagi berada dalam satu tangan (shareholders), melainkan berada pada banyak tangan, yaitu stakeholders. Diversifikasi kekuasaan ekonomi ini dalam konsep syari'ah sangat direkomendasikan, mengingat syari'ah melarang beredarnya kekayaan hanya di kalangan tertentu saja.

Oleh karena itu, proprietary theory dan entity theory tidak akan mampu mewadahi kemajemukan masyarakat (stakeholders) dan bisnis yang ada saat ini. Untuk mengatasi hal ini diperlukan wadah alternatif yang lebih tepat dan sesuai dengan lingkungannya. Wadah tersebut, seperti yang disampaikan oleh beberapa penulis (Harahap 1997; Triyuwono 2000b) adalah enterprise theory.

Mengenai enterprise theory ini Harahap $(1997,154-155)$ berpendapat bahwa teori tersebut lebih lengkap dibandingkan dengan teori yang lain, karena ia melingkupi aspek sosial dan pertanggung-jawaban seba- 
gaimana diungkapkan dalam pernyataan berikut ini:

Kalau ada pernyataan mengenai postulat, konsep, dan prinsip akuntansi Islam itu maka saat ini yang bisa saya jawab adalah masalah ini tidak semudah yang dibayangkan. Tentunya untuk merumuskan ini perlu pengkajian multi dimensi. Yang jelas literatur sampai saat ini belum bisa menjelaskannya. Tapi dari postulat, konsep, dan prinsip yang ada dapat kita saring mana yang sejalan dengan konsep Islam. Misalnya konsep mana yang dipakai dari ketiga konsep: proprietary theory, entity theory, dan enterprise theory? Maka akan saya jawab enterprise theory karena lebih mencakup aspek sosial dan pertanggungjawaban... Enterprise theory menjelaskan bahwa akuntansi harus melayani bukan saja pemilik perusahaan, tetapi juga masyarakat.

Pendapat serupa juga diungkapkan oleh Triyuwono $(2000 \mathrm{~b}, 24)$ yang mengatakan bahwa:

Akuntansi syari'ah tidak saja sebagai bentuk akuntabilitas (accountability) manajemen terhadap pemilik perusahaan (stockholders), tetapi juga sebagai akuntabilitas kepada stakeholders dan Tuhan.

Dengan memperhatikan beberapa pendapat di atas, maka dapat dipahami bahwa konsep teoritis yang mampu memberikan dasar dalam pembentukan prinsip dan teknik akuntansi yang menghasilkan bentuk akuntabilitas dan informasi yang dibutuhkan oleh stakeholders adalah enterprise theory.

Konsep ini memang sangat dekat dengan syari'ah. Namun, dari sudut pandang syari'ah, ia belum mengakui adanya partisipan lain yang secara tidak langsung (indirect participants) memberikan kontribusi ekonomi. Artinya, konsep ini belum bisa dijadikan sebuah justifikasi bahwa enterprise the- ory telah menjadi konsep teoritis akuntansi syari'ah sebelum teori tersebut mengakui eksistensi dari indirect participants. Mengapa demikian? Secara normatif, indirect participants ini mempunyai hak atas nilai tambah yang diciptakan oleh perusahaan. Oleh karena itu, Triyuwono (2002, forthcoming) dan Slamet (2001) mengajukan konsep shari'ah enterprise theory dengan jalan memasukkan kepentingan indirect participants ke dalam "elit" kekuasaan economi direct participants (seperti, shareholders, management, employess, customers, suppliers, government, ect) dalam distribusi nilai tambah (value added) (lihat juga Baydoun dan Willett 1994).

\section{EPISTEMOLOGI SINERGI OPOSISI BINER}

Diskusi di atas secara implicit menunjukkan bahwa pemilik perusahaan dalam proprietary theory dan entity theory merupakan pihak yang sangat penting dan sentral. Sementara enterprise theory berpikir lebih holistik dengan cara mengakui "pihak lain" (the others) selain pemilik perusahaan (shareholders) sebagai pihak yang juga memegang peranan penting bagi kesenambungan hidup perusahaan.

"Yang sentral" dan "yang lain" dalam enterprise theory diakui dan akomodasi dalam satu wadah. Masuknya "yang lain" ke "yang sentral," dalam wacana posmodernisme sering dikenal dengan istilah dekonstruksi (deconstruction). Posmodernisme sebagai anti-tesis dari modernisme tidak menyepakati pola pikir oposisi biner (misalnya, bentuk/substansi, salah/benar, egoistik/altruistik, kompetisi/kooperasi, dan lainlainnya) yang diadopsi oleh modernisme. Dengan pola pikir oposisi biner ini posisi yang satu cenderung meniadakan atau memarjinalkan posisi yang lain, misalnya "bentuk" memarjinalkan "substansi," atau "kompetisi" memarjinalkan "kooperasi," atau shareholders memarjinalkan manaje- 
men, pegawai, pelanggan, kreditor, pemerintah, dan lain-lain.

Sehubungan dengan itu, Hines (1992, 328) berpendapat bahwa akuntansi modern sebagai produk dari budaya modernitascendrung untuk memarjinalkan the negative spaces (seperti, pauses, punctuations, rests, breaths and silences) atau "yang lain" dari sebuah totalitas. Dan memang itulah budaya modernitas; ia sangat sarat dengan nilai-nilai maskulin, dan sebaliknya memarjinalkan nilai-nilai feminin. Budaya semacam ini jelas akan merusak peradaban manusia itu sendiri dan lingkungannya.

Kearifan tradisi Islam telah mengajarkan azas "berpasangan" dalam takaran yang seimbang (QS 36:36). Kearifan tradisi Tao juga berpegang pada konsep berpasangan, yaitu Yin (feminin) dan Yang (maskulin). Konsep ini sebetulnya sudah sunnatullah. Namun budaya modernitas cenderung mengabaikan nilai-nilai feminin dari segala aspek kehidupan; demikian juga di dunia akuntansi seperti yang dikatakan Hines (1992, 328) di bawah ini:

The language of accounting is the arch-communicators and social constructor of unbalanced Yang consciousness, society, and environment... it is hard, dry, impersonal, objective, explicit, outer-focus, action-oriented, analytic, dualistic, quantitative, liner, rationalist, reductionist and materialist.

Dengan karakter semacam ini, akuntansi menjadi "keras," "impersonal," dan "materialis." Karakter inilah yang sebetulnya dipancarkan oleh akuntansi modern melalui accounting information. Dan, sayangnya pengguna informasi tidak sensitif terhadap kandungan nilai informasi yang digunakannya, sehingga tidak aneh jika keputusan-keputusan bisnis yang diambil juga memiliki karakter yang sama. Karakter ini semakin memperkuat realitas modernitas yang hidup sampai saat ini.
Secara ideal, oposisi biner harus didudukkan secara berpasangan sebagaimana kearifan tradisi Islam dan Tao. Artinya, mendudukkan sesuatu yang "bertentangan" dalam posisi yang sinergis, sebagaimana ditemukan pada "penggabungan" aliran listrik "negatif" dengan "positif." Tanpa penggabung dua hal yang berbeda ini, mustahil peradaban manusia saat ini merasakan manfaat yang luar biasa dari aliran listrik. Aliran listrik "negatif" sama sekali tidak bermanfaat tanpa dikawinkan dengan aliran listrik "positif." Demikian juga dengan nilai-nilai yang lain, seperti sinergi antara egoistik dengan altruistik, antara kuantitatif dengan kualitatif, impersonal dengan personal, obyektif dengan subyektif, dan lain-lainnya (lihat tabel di bawah ini).

Tabel 1

\section{Kualitas Nilai-nilai Maskulin (Yang) dan Feminin (Yin).}

\begin{tabular}{|l|l|}
\hline Yang & Yin \\
\hline Action & Stillness, silence \\
\hline Cause-effect & Synchronicity \\
\hline Consciousness & Unconsciousness \\
\hline Doing & Being \\
\hline Dry & Moist \\
\hline Egoistic & Altruistic \\
\hline Exterior & Interior \\
\hline Full & Empty \\
\hline Hard & Soft \\
\hline Impersonal & Personal \\
\hline Logic/rational & Intuition \\
\hline Material & Spiritual \\
\hline Objective & Subjective \\
\hline Productive & Receptive \\
\hline Progress & Integration \\
\hline Providing & Caring \\
\hline Quantitative & Qualitative \\
\hline Sequential & Simultaneous \\
\hline Standardization & Proliferation \\
\hline Sumber: Hines (1992, $327 ;$ dimodifiki)
\end{tabular}

Sumber: Hines (1992, 327; dimodifikasi) 
Akuntansi modern yang sampai saat ini mendominasi praktik akuntansi memiliki sifat-sifat maskulin. Dan dalam dunia modernitas tampaknya sangat aneh bila akuntansi modern mengadopsi nilai-nilai feminin. Keanehan itu akan terlihat pada contoh yang disajikan oleh Hines (1992, 330) berikut ini: ...accounting practice is objectives and impersonal in the dividing up and distributing of parts or all of entities. Payments and distributions of entities are made on the basis of enforceable, legal claims. The "economy," which consist of economic entities, does not survive and "grow," in accounting terms, by nurturing and caring for people, animals and the environment, and so it would not be "rational" or "reasonable" to make distribution based on needs.

Sebagaimana diungkapkan di atas, sebuah entitas bisnis - yang dibahasakan dengan akuntansi - tidak dapat dikatakan survive dan tumbuh dengan memberi "makan" dan "memelihara" "yang lain" (masyarakat yang tidak memiliki hubungan langsung dengan perusahaan, hewan, dan lingkungan alam). Akuntansi moderm, dengan demikian, memang objective dan impersonal. Karakter maskulin yang diadopsi akuntansi modern ini jelas mereduksi realitas yang sebenarnya. Ia menjadi sangat parsial. Oleh karena itu, diperlukan suatu upaya yang dapat membuat akuntansi menjadi lebih holistik sehingga dapat merepresentasikan realitas yang kompleks secara lebih tepat.

Langkah yang dapat dilakukan adalah dengan cara mengawinkan sifat-sifat yang bertentangan (oposisi biner) ke dalam satu kesatuan. Misalnya, mengawinkan sifat egoistik dengan altruistik, sifat materialistik dengan spiritualistik, rasional dengan intuisi, impersonal dengan personal, kuantitatif dengan kualitatif, standarisasi dengan proliferasi, dan lain-lainnya (lihat tabel 1). Inilah yang dimaksud dengan sinergi oposisi biner.
Dengan sinergi ini diharapkan bahwa akuntansi akan memiliki power yang lebih kuat melalui pancaran informasi akuntansi yang dihasilkannya untuk kemudian membentuk realitas yang lebih humanis, emansipatoris, transendental, dan teleologikal.

Illustrasi di atas menghantarkan kita pada suatu konsep bahwa pada dasarnya akuntansi syari'ah secara epistemologis mengadopsi sinergi oposisi biner. Dengan epistemologi ini pula akuntansi syari'ah dapat memformulasikan tujuan dasar laporan keuangannya.

Secara normatif tujuan laporan keuangan akuntansi syari'ah dapat diformulasikan sebagai perpaduan antara aspekaspek yang bersifat materialistik dan spiritualistik; perpaduan "materi" dan "spirit."

Akuntansi modern telah memiliki sifat materialistik, yaitu sifat maskulin yang berorientasi pada aspek ekonomi, pengukuran-pengukuran yang eksak, kuantitatif, dan lain sebaginya seperti yang diutarakan oleh Hines $(1992,328)$ di bawah ini:

From the viewpoint of accounting practice there is a "hard" world "out there." There is an "economy" in society, and in that "economy" there are discrete and bounded "entities" which are quantifiable, inasmuch as accounting practices can measure" them, in hard numbers. Measurements can be made of their "size" (e.g. gross assets, net assets, turnover), "health" (e.g. capital plus net worth), "growth" (e.g. net profit...) and their "yield" (e.g. dividends to profit, or net assets).

Ketidak-seimbangan ini akan menjadikan akuntansi, akuntan, dan penggunanya menjadi keras, mekanis, dan kering dari nilai-nilai kemanusiaan yang utuh. Singkatnya, akan terjadi disfunctional behaviour dari manusia yang utuh, alienasi manusia dari fitrahnya. Semuanya ini disebabkan karena adanya reduksi nilai yang dilakukan oleh akuntansi modern. Panda- 
ngan ini didukung oleh Chwastiak (1999, 438) yang mengatakan bahwa:

Accounting limits the concept of gain and loss to the financial wealth created or depleted by corporate actions. In so doing, it assists with perpetuating the myth that human happiness lies in acquiring material possessions. For accounting to play a transforming role, its energy must be converted from a force that ensnares the human mind set to the status quo to one that engages and expands the human being's infinite possibilities. Hence rather than positing the accumulation of wealth as the only rational reason for engaging in economic action, accounting could play a reformative role by representing value as being created by economic activities that respect and enhance the innate merit in others and nature

Akuntansi memang telah melakukan reduksi dengan mengkonsep laba dan rugi pada aspek keuangan saja, atau aspek materi saja. Konsep ini memperkuat persepsi manusia bahwa kebahagiaan itu adalah perolehan materi. Semakin banyak materi yang diperoleh seseorang, maka semakim bahagia orang tersebut. Tetapi dalam kenyataannya tidak demikian, materi bukan satu-satunya aspek dari kebahagian. Oleh karena itu, akuntansi mempunyai peluang untuk melakukan perubahan dengan menggunakan peran transformatifnya, yaitu dengan memasukkan "yang lain" pada yang ada di "sentral." Dengan kata lain, perlu mengawinkan "materi" (ekonomi, uang, struktur, dan lain-lainnya) dengan "spirit" (etika, kasih sayang, dan lain-lainnya). Dengan demikian, tujuan dasar dari laporan keuangan akuntansi syari'ah adalah perpaduan antara "materi" dan "spirit."

\section{TUJUAN DASAR LAPORAN} KEUANGAN AKUNTANSI SYARI'AH

Dari diskusi di atas dapat kita formulasikan bahwa tujuan dasar laporan keuangan akuntansi syari'ah yang bersifat "materi" adalah untuk pemberian informasi (akuntansi), sedangkan yang bersifat "spirit" adalah untuk akuntabilitas (cf. Baydoun and Willett 1994). Kedua tujuan ini mutually inclusive, tujuan yang satu tidak dapat meniadakan yang lain; keduanya berada dalam kesatuan (unity) sebagaimana bersatunya badan dan ruh kita. Pemberian informasi seolah-olah merupakan "badan," sedangkan akuntabilitas adalah "ruh." "Badan" tidak akan eksis tanpa "ruh." Demikian juga sebaliknya, "ruh" tidak dapat membumi tanpa "badan."

"Materi" dan "spirit" memang berbeda, tetapi keduanya tidak dapat dipisahkan. Dalam wacana filsafat idealisme, "spirit" dianggap lebih abadi dibandingkan dengan "materi." Persisnya, menurut Idealisme Jerman dikatakan bahwa "the ultimate reality of the universe is spiritual rather than material in nature (Burrell and Morgan 1979, 326). Hal yang sama juga diungkapkan Triyuwono (2000c, 243; lihat juga Dhaouadi 1993) bahwa "the spiritual dimension is the departing point and more powerful than the materialistic one in their continuing dynamic interaction. However, they are complementary with a preferential difference." Meskipun "spirit" lebih tinggi dan lebih kuat dibanding "materi," tetapi ia tidak terpisah dengan "materi."

Kalau kita kembalikan lagi dalam konteks akuntansi syari'ah, maka dapat kita katakan bahwa posisi akuntabilitas lebih substansial, atau menjadi "jiwa," atau menjadi dasar "etika," dari (pada) pemberian informasi. Dengan demikian, akuntabilitas merupakan spirit (ualitas) akuntansi syari'ah. Tanpa akuntabilitas, akuntansi syari'ah menjadi instrumen "mati" yang mekanis sebagaimana kita temukan pada akuntansi 
modern. Konsep akuntabilitas di sini sangat terkait dengan tradisi dan pamahaman Islam tentang Tuhan, manusia, dan alam semesta (lihat Triyuwono 1997).

Dalam tradisi Islam, manusia adalah khalifatullah fil ardh (wakil Tuhan di bumi) (lihat QS. 2:30; 35:39) dengan misi khusus "menyebarkan rahmat bagi seluruh alam" (QS.38:26) sebagai amanah dari Tuhan. Dengan misi khusus ini, manusia diberi amanah untuk mengelola bumi berdasarkan keinginan Tuhan (the will of God). Ini artinya bahwa manusia berkewajiban mengelola bumi berdasarkan pada etika syari'ah (Triyuwono 1997, 18-19), yang konsekuensinya harus dipertanggung-jawabkan kepada Tuhan. Ini merupakan premis utama dari akuntabilitas, yaitu akuntabilitas vertikal.

Dalam konteks akuntansi, manusia seolah-olah mengikat kontrak dengan Tuhan. Dalam kontrak tersebut Tuhan sebagai (The Ultimate Principal) menugaskan manusia untuk menyebarkan rahmat/kesejahteraan (dalam bentuk ekonomi, sosial, spiritual, politik, dan lain-lainnya) pada manusia yang lain (stakeholders) dan alam (natural environment). Konsekuensinya, manusia memang harus bertanggungjawab atas tugas yang dibebankan ini kepada Tuhan (lihat Triyuwono dan Roekhuddin 2000, 157-164) berdasarkan hukum-hukumNya - akuntabilitas vertikal (vertical accountability).

Namun harus diakui bahwa tugas manusia itu adalah tugas yang membumi. Tugas tersebut menyangkut penciptaan dan penyebaran rahmat kepada manusia yang lain dan lingkungan alam dalam bentuk aktivitas bisnis. Dalam konteks mikro dapat diartikan bahwa sebuah entitas bisnis telah melakukan kontrak sosial (social contract) dengan masyarakat dan alam. Oleh karena itu, hubungan antara seorang agent (manajemen) dengan masyarakat dan alam tidak dapat dijustifikasi dengan entity theory atau principal-agent relationship, tetapi dengan konsep shari'ah enterprise theory seperti yang telah disinggung di atas. Sebagai konsekuensi dari kontrak tersebut, seorang agent harus bertanggungjawab kepada masyarakat (stakeholders) dan alam (universe) (lihat Triyuwono dan Roekhuddin 2000, 157-164). Hubungan pertanggungjawaban pada tingkat ini dinamakan akuntabilitas horizontal (horizontal accountability).

Jadi, pada dasarnya akuntansi syari'ah merupakan instrumen akuntabilitas yang digunakan oleh manajemen kepada Tuhan (akuntabilitas vertikal), stakeholders, dan alam (akuntabilitas horizontal). Pemikiran ini mempunyai dua implikasi. Pertama, akuntansi syari' ah harus dibangun sedemikian rupa berdasarkan nilai-nilai etika (dalam hal ini adalah etika syari'ah) sehingga "bentuk" akuntansi syari'ah (dan konsekuensinya informasi akuntansi yang disajikan) menjadi lebih adil; tidak berat sebelah, sebagaimana kita temukan pada akuntansi modern yang memihak kepada para kapitalis (dan kreditor) dan memenangkan nilai-nilai maskulin. Kedua, praktik bisnis dan akuntansi yang dilakukan manajemen juga harus berdasarkan pada nilai-nilai etika syari'ah. Sehingga, jika dua implikasi ini benar-benar ada, maka akuntabilitas yang dilakukan oleh manajemen adalah akuntabilitas yang suci. Atau dengan kata lain, manajemen menyajikan "persembahan" yang suci kepada Tuhan, dan sebaliknya Tuhan menerima persembahan suci ini dengan ridho. Inilah sebetulnya bentuk "peribadatan" yang nyata dari manusia kepada Tuhannya (lihat QS. 51:56).

Dari penjelasan di atas kita dapat memahami bahwa akuntabilitas memang merupakan spirit dari bentuk akuntansi syari'ah sekaligus juga merupakan spirit dari praktik bisnis dan akuntansi yang dilakukan oleh manajemen.

Lalu bagaimana dengan pemberian informasi? Akuntabilitas sebagai representasi dari "spirit" merupakan satu sisi dari satu uang logam akuntansi syari'ah. Sisi yang lain adalah pemberian informasi seba- 
gai perwujudan dari "materi." Pemberian informasi sebetulnya merupakan konsekuensi logis dari adanya akuntabilitas. Akuntabilitas (dengan dasar nilai etika syari'ah) menjadi spirit yang mendasari bentuk akuntansi dan informasi akuntansi. Bentuk dan informasi akuntansi dengan spirit etika syari'ah ini digunakan untuk pengambilan keputusan oleh pihak-pihak yang berkepentingan. Karena bentuk dan informasi akuntansi tersebut berdasarkan etika syari'ah, maka keputusan-keputusan yang diambil juga akan mengandung nilainilai syari'ah; dan konsekuensinya, realitas yang diciptakan adalah realitas yang bernuansa syari'ah. Realitas yang demikian inilah yang dimaksuid dengan realitas yang bertauhid (lihat Triyuwono 1996, 57-58).

Perlu diketahui bahwa dalam pemikiran ini, pemberian informasi tidak terbatas pada pemberian informasi kuantitatif, sebagaimana pada akuntansi modern, tetapi juga melingkupi informasi kualitatif, baik yang bersifat ekonomi maupun yang bersifat sosial, spiritual, dan politik bisnis (tetap konsisten dengan epistemologi sinergi oposisi biner. Hal ini demikian, karena dalam tradisi Islam, konsep kesejahteraan (wealth) tidak saja meliputi kesejahteraan ekonomi, tetapi juga kesejahteraan sosial, spiritual, dan politik. Ini berbeda dengan konsep kapitalisme yang mereduksi kesejahteraan ke dalam bentuk kesejahteraan ekonomi saja (lihat juga Hines 1992; Chwastiak 1999).

\section{PENUTUP}

Akuntansi syari'ah tidak dapat dipahami melalui pendekatan konvensional, karena ia merupakan instrumen bisnis yang terkait dengan Tuhan, manusia, dan alam. Keterkaitannya dengan Tuhan, manusia, dan alam ini telah membedakan akuntansi syari'ah dengan akuntansi modern secara signifikan, baik pada nilai yang terkandung di dalamnya maupun pada bentuk teori dan tujuan dasarnya (the basic objective).

Dalam konteks bahasan ini, manusia diasumsikan sebagai khalifatullah fil ardh yang membawa amanah Tuhan untuk menciptakan dan menyebarkan rahmat bagi seluruh alam. Pandangan dunia (worldview) atas manusia sebagai khalifatullah fil ardh membawa konsekuensi penghambaan manusia terhadap Tuhan dan penghormatan manusia terhadap manusia lain dan alam. Pandangan ini sangat berbeda dengan pandangan dunia modern yang melihat manusia sebagai "penguasa" alam. Pandangan dunia semacam ini membawa konsekuensi pada bentuk akuntansi modern yang melakukan eksploitasi manusia atas manusia dan eksploitasi manusia atas alam (lihan Hines 1993; Chwastiak 1999).

Menganggap manusia sebagai khalifatullah fil ardh membawa akuntansi dengan wajah yang lebih humanis, emansipatoris, transendental, dan teleologikal yang kemudian terlihat pada tujuan dasarnya, yaitu akuntabilitas dan pemberian informasi. Formulasi tujuan dasar ini diderivasi dari epistemologi sinergi oposisi biner, yaitu epistemologi bernuansa syari'ah. Dengan tujuan dasar semacam ini, bentuk dan informasi akuntansi syari'ah diharapkan dapat mempengaruhi terciptanya realitas kehidupan bisnis yang sarat dengan nilai-nilai etika syari'ah dan dapat menghantarkan manusia pada "kesadaran ketuhanan" (Godconsciousness).

\section{DAFTAR PUSTAKA}

Baiman, S. 1990. Agency research in managerial accounting: a second look. Accounting, Organizations, and Society: 341-371.

Baydoun, N and Roger Willett. 1994. Islamic accounting theory. The AAANZ Annual Conference. 
Burrell, Gibson and Gareth Morgan. 1979. Sociological Paradigms and Organisational Analysis: Elements of the Sociology of Corporate Life. London: Heinemann.

Chwastiak, Michele. 1999. Deconstructing the principal-agent model: a view from the bottom. Critical Perspective on Accounting. Vol.10. No. 4: 425-441.

Dhaouadi, Mahmoud. 1993. Reflections into the spirit of the Islamic corpus oh knowledge and the rise of the new science. The American Journal of Islamic Social Sciences. Vol. 10. No. 2: 153-164.

Gambling, Trevor and Rifaat Ahmed Abdel Karim. 1991. Business and Accounting Ethics in Islam. London: Mansell.

Harahap, Sofyan Syafri, 1996. Akuntansi Islam. Jakarta: Bumi Aksara.

Hines, D. Ruth.1992. Accounting Filling The Negative Space. Accounting, Organization, and Society 17 (3/4): 313-41.

Hines, D. Ruth. 1992. Accounting: filling the negative space. Accounting, Organization, and Society. Vol. 17. No. 3/4: 313-341.

Kam, Vernon. 1990. Accounting Theory. Second edition. New York: John Wiley \& Sons.

Mathews, MR and MHB Perera. 1993. Accounting Theory and Development. Melbourne: Thomas Nelson Australia.

Setiabudi, Hendry Y. 2000. Tinjauan komparatif-interpretif ekuitas sebagai konsep kepemilikan dalam akar epistemologi kapitalisme, sosialisme, dan Islam. Skripsi. Malang: Fakultas Ekonomi- Universitas Brawijaya.

Slamet, M. 2001. Enterprise Theory dalam konstruksi akuntansi syari'ah (studi teoritis pada konsep akuntansi syari'ah). Skripsi. Malang: Fakultas Ekonomi - Universitas Brawijaya.

Triyuwono, Iwan dan Moh. As'udi. 2001. Akuntansi Syariah: Memformulasikan Konsep Laba dalam Konteks Metafora Zakat. Jakarta: Salemba Empat.

Triyuwono, Iwan dan Roekhuddin. 2000. Konsistensi praktik sistem pengendalian intern dan akuntabilitas pada Lazis (studi kasus di Lazis X Jakarta). Jurnal Riset Akuntansi Indonesia. Vol. 3. No. 2: 151-167.

Triyuwono, Iwan. 1996. Teori akuntansi berhadapan dengan nilai-nilai keislaman. Jurnal Ulumul Qur'an. Vol. VI. No. 5: 44-61.

Triyuwono, Iwan. 1997. "Akuntansi Syari'ah" dan Koperasi Mencari Bentuk dalam Metafora Amanah. Jurnal Akuntansi dan Auditing Indonesia. Vol. 1. No. 1: 1-46.

Triyuwono, Iwan. 2000a. Organisasi dan Akuntansi Syari'ah. Yogyakarta: LKiS.

Triyuwono, Iwan. 2000b. Akuntansi Syari'ah: Implementasi Nilai keadilan dalam Format Metafora Amanah, Jurnal Akuntansi dan Auditing Indonesia, Vol 4. No1: 1-34.

Triyuwono, Iwan. 2000c. Shari'ate accounting: an ethical construction of accounting discipline. Gadjah Mada International Journal of Business. Vol. 2. No. 2:233-251.

Triyuwono, Iwan. 2002. Metafora amanah dan shari'ah enterprise theory sebagai konsep dasar untuk membentuk akuntansisyari'ah. Jurnal Akuntansi dan Auditing Indonesia (forthcoming). 